\title{
ANALISIS PENGANGGURAN DAN KEMISKINAN DI PROVINSI JAMBI
}

\section{Oleh:}

\author{
Ahmad Soleh ${ }^{1}$ \\ Dosen Tetap Universitas Muhammadiyah Jambi ${ }^{1}$ \\ mas.soleh@yahoo.com \\ Prima Audia Daniel ${ }^{2}$ \\ Dosen Tetap Universitas Muhammadiyah Jambi² \\ Primaaudia@,gmail.com \\ Siswoyo ${ }^{3}$ \\ Dosen Tetap Universitas Muhammadiyah Jambi ${ }^{3}$ \\ Siswoyosis@,gmail.com
}

\begin{abstract}
Abstrak
Penelitian ini bertujuan mendeksripsikan dinamika tingkat pengangguran dan kemiskinan di Provinsi Jambi dan menganalisis hubungan antara tingkat pengangguran dan kemiskinan yang terjadi di Provinsi Jambi. Metode penelitian yang digunakan dalam penelitian adalah metode deskriptif kualitatif dan kuantitatif dengan menggunakan data sekunder.

Hasil dari penelitian menunjukkan bahwa terdapat hubungan yang searah (negatif) antara pengangguran dan kemiskinan. Dimana ketika terjadi penurunan tingkat pengangguran maka akan menurunkan jumlah kemiskinan di Provinsi Jambi.
\end{abstract}

\section{PENDAHULUAN}

Dua permasalahan utama yang masih menjadi masalah klasik yang sulit di atasi adalah samai saat ini adalah pengangguran dan kemiskinan. Dimana kedua masalah tersebut mempunyai keterkaitan yang erat satu sama lainnya. Ketika terjadi peningkatan pengangguran maka akan memberikan dampak peningkatan kemiskinan dan demikian sebaliknya meningkatnya kemiskinan juga berhubungan dengan pengangguran.

Untuk itu kedua indikator tersebut sering digunakan sebagai ukuran dalam menilai seberapa jauh capaian dan keberhasilan dari pembangunan yang telah dicapai suatu negara. Semakin sedikit angka pengangguran pada suatu negara atau wilayah tersebut maka semakin baik pembangunan negara tersebut demikian juga sebaliknya semakin besar jumlah tenaga kerja yang menganggur maka semakin gagal pembangunan dalam negara tersebut. Karna kita tau bahwa besarnya efek yang ditimbulkan dari adanya pengangguran dalam suatu negara. Pengangguran sendiri terjadi sebagai akibat meningkatnya jumlah tenaga kerja yang lebih besar dibandingkan dengan ketersediaan dan perkembangan jumlah tenaga kerja yang terjadi sehingga menciptakan kesenjangan antara demand dan supply antara permintaan tenaga kerja dan penawaran tenaga. 
Demikian juga yang terjadi pada pada indikator kemiskinan yang mana kemiskinan juga dijadikan sebagai ukuran dalam melihat sejauhmana keberhasilan pembangunan. Kondisi ini dapat dilihat dari besarnya jumlah peduduk miskinnya. Semakin banyak jumlah penduduk miskin artinya semakin kurang berhasil pembangunan dan demikian juga sebaliknya

Dengan melihat pentingnya penanganan dari kedunya maka perlu dilakukan penelitian lebih lanjut terkait dengan dinamika yang menjadi permasalahan pengangguran dan kemiskinan serta hubungan antara keduanya sehingga diperoleh kesimpulan yang dapat digunakan dalam pengentasan pengangguran dan kemiskinan. Dalam analisa penelitian ini penulis membatasi ruang lingkup penelitian pada wilayah Provinsi Jambi.

\section{TINJAUAN PUSTAKA}

\section{Pengangguran}

Pengangguran adalah adalah orang yang tidak bekerja dan yang 1) secara aktif mencari pekerjaan selama 4 (empat) minggu sebelumnya, atau 2) sedang menunggu dipanggil kembali suatu pekerjaan setelah diberhentikan, atau 3) sedang menunggu untuk melapor atas pekerjaan yang baru dalam jangka waktu 4 (empat) minggu (Dornbusch, dkk dalam Amir, 2007). Pengangguran merupakan salah satu masalah utama dalam jangka pendek yang selalu dihadapi setiap negara. Karena itu, setiap perekonomian dan negara pasti menghadapi masalah pengangguran, yaitu pengangguran alamiah (natural rate of unemployment).

Pengangguran timbul selain disebabkan karena kelebihan tenaga kerja dibandingkan lapangan kerja yang tersedia, juga disebabkan karena faktor non ekonomi. Faktor non ekonomi tersebut antara lain pranata dan pola tingkah laku yang berhubungan dengan hak kerja, serta ketidakcocokan kualifikasi pekerjaan dengan tingkat keahlian atau pendidikan yang dimiliki, selera dan atau aspirasi mereka. Pengangguran secara umum (Simanjuntak dalam Amir, 2007) dapat dirinci sebagai berikut :

1. Pengangguran friksi (frictional unemployment)

2. Pengangguran musiman (seasonal unemployment)

3. Pengangguran struktural (structural unemployment)

4. Pengangguran yang diakibatkan oleh kelebihan yang kronis dari total penawaran tenaga kerja

5. Pengangguran tidak kentara (disgued unemployment)

6. Setengah menganggur kentara (visible unemployment)

7. Setengah menganggur potensial (potential unemployment)

\section{Kemiskinan}


Kemiskinan adalah ketidakmampuan seseorang dalam memenuhi kebutuhan dasar, atau ketidakmampuan seseorang, suatu keluarga atau sekelompok masayrakat untuk memenuhi kebutuhan dasarnya. Kemiskinan saat ini tidak lagi dlihat dari kemiskinan materi semata, tetapi dapat dilihat dari apakah seseorang, suatu keluarga atau sekelompok masyarakat memperoleh kebebasan dan kesempatan untuk mendapatkan berbagai hak dasar seperti pendidikan, kesehatan dan sebagainya (Amir, 2007).

Fenomena kemiskinan merupakan fenomena yang terkait dengan banyak aspek baik aspek ekonomi, sosial, politik, dan budaya. Lingkaran perangkap kemiskinan (the vicious circles) merupakan suatu rangkaian kekuatan-kekuatan yang saling mempengaruhi satu sama lain sedemikian rupa sehingga menimbulkan keadaan di mana suatu negara akan tetap miskin dan akan menghadapi banyak kesulitan untuk mencapai tingkat pertumbuhan ekonomi yang tinggi. Nurkse menyatakan bahwa lingkaran kemiskinan bukan saja disebabkan oleh ketiadaan pembangunan pada masa lalu tetapi juga menimbulkan hambatan pembangunan di masa yang akan datang. Fenomena lingkaran perangkap kemiskinan (the vicious circles) digambarkan berikut :

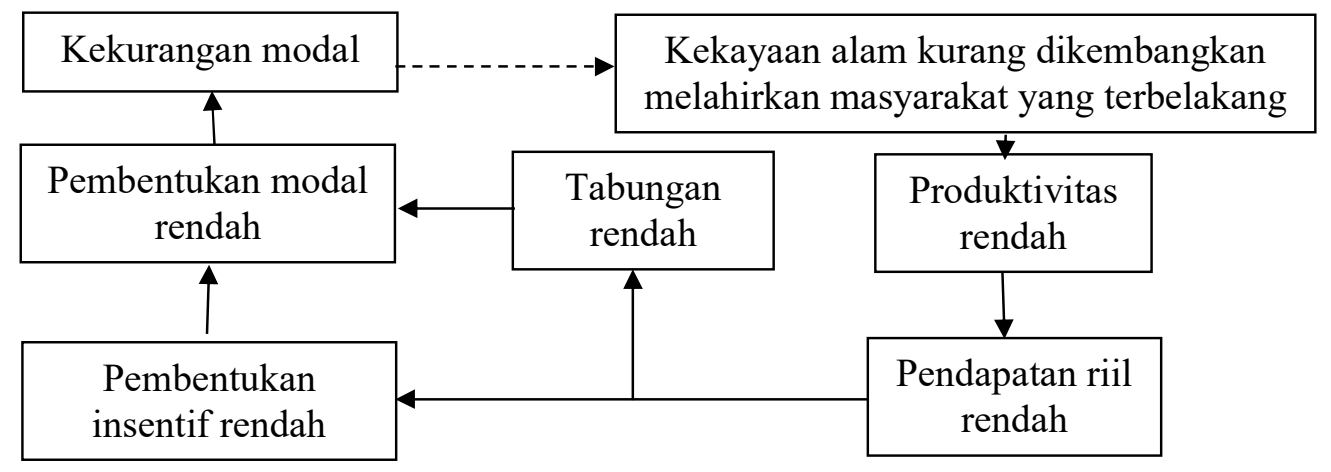

\section{Gambar 1. Lingkaran Perangkap Kemiskinan (The Vicious Circles) Sumber : Meier \& Baldwin dalam Yuliadi, 2007}

Tinggi rendahnya tingkat kesmikinan di suatu negara tergantung pada dua faktor utama, yakni : (1) tingkat pendapatan nasional rata-rata, dan (2) lebar sempitnya kesenjangan dalam distribusi pendapatan, jelas, bahwa setinggi apa pun tingkat pendapatan nasional per kapita yang dicapai oleh suatu negara, selama distribusi pendapatan tidak merata, maka tingkat kemiskinan di negara tersebut pasti akan tetap parah. Demikian pula sebaliknya, semerata apapun distribusi pendapatan di suatu negara, jika tingkat pendapatan nasional rata-ratanya tidak mengalami perbaikan, maka kemelaratan juga akan semakin meluas (Todaro, 2000). 
Pendapatan riil, distribusi pendapatan dan kemiskinan merupakan aspek yang sangat penting bagi penentuan kesejahteraan masyarakat, meskipun arti pentingnya berbeda. Kemiskinan menurut Jeffrey dalam Amir (2007) ditandai oleh ketiadaan atau tidak dimilikinya:

1) Human capital (kesehatan, pendidikan dan nutrisi yang baik),

2) Bussines capital,

3) Infrastruktur (jalan, listrik, air bersih, sanitasi, perlindungan lingkungan lingkungan dan sarana publik lainnya),

4) Natural capital (lahan),

5) Public institusional capital (administrasi publik yang dikelola dengan baik, sistem pengadilan yang bersih dan polisi yang baik),

6) Knowledge capital (modal ilmu pengetahuan).

\section{METODE PENELITIAN}

Metode analisis data yang digunakan dalam penelitian ini adalah deskriptif kualitatif dan kuantitatif dengan menggunakan data sekunder yang diperoleh dari literature dan instansi terkait dengan penelitian. Untuk menganalisis permasalahan pertama digunakan alat deskriptif kualitatif sedangkan untuk menjawab permasalahan kedua digunakan model korelasi person yang digunakan untuk melihat berapa besar pengaruh pengangguran terhadap kemiskinan dengan menggunakan rumus korelasi Pearson Product Moment sebagai berikut: (Kakisina dan Rumansara, 2000).

Dimana :

$$
r_{1}=\frac{n \sum X_{1} Y-\left(\sum Y\right)\left(\sum X_{1}\right)}{\sqrt{\left(n \sum Y^{2}-\left(\sum Y\right)^{2}\right)\left(n \sum X_{1}^{2}-\left(X_{1}\right)^{2}\right)}}
$$

$\mathrm{r}_{1}=$ nilai korelasi antara $\mathrm{X}$ (Pengangguran) dengan $\mathrm{Y}$ (Kemiskinan)

$\mathrm{n}=$ Jumlah Periode

$\mathrm{X}=$ Pengangguran

$\mathrm{Y}=$ Kemiskinan

Adapun kriteria koefisien korelasi adalah sebagai berikut (Sugiono 2001) :

\begin{tabular}{|c|c|}
\hline KORELASI HUBUNGAN & KRITERIA \\
\hline $0,80-1,000$ & Sangat Kuat \\
$0,60-0,799$ & Kuat \\
$0,40-0,599$ & Sedang \\
$0,20-0,399$ & Lemah \\
$0,00-0,199$ & Sangat Lemah \\
\hline
\end{tabular}




\section{HASIL PENELITIAN}

\section{a. Pengangguran dan Kemiskinan di Provinsi Jambi}

Pengangguran dan kemiskinan merupakan masalah penting dalam perekonomian suatu negara. Keduanya sering digunakan sebagai indikator dalam menilai keberhasilan pembangunan dan menjadi ukuran kesuksesan suatu negara dalam mensejahterakan rakyatnya. Faktor utama penyebab tingginya angka pengangguran adalah meningkatnya jumlah tenaga kerja yang lebih besar yang tidak diimbangi dengan meningkatnya jumlah lapangan kerja yang tersedia. Sementara dampak yang ditimbulkan dari meningkatnya pengangguran berdampak pada meningkatnya kemiskiskinan. Berikut adalah data jumlah pengangguran dan kemiskinan di Provinsi Jambi selama periode 2000-2015.

Tabel 1. Perkembangan Jumlah Pengangguran \& Jumlah Penduduk Miskin di Provinsi Jambi Tahun 2000-2015

\begin{tabular}{|c|c|c|c|c|}
\hline Tahun & $\begin{array}{c}\text { Pengangguran } \\
\text { (Orang) }\end{array}$ & $\mathbf{( \% )}$ & $\begin{array}{c}\text { Penduduk Miskin } \\
\text { (Jiwa) }\end{array}$ & $(\%)$ \\
\hline 2000 & 38.400 & - & 504.900 & 480.400 \\
\hline \\
\hline 2001 & 60.240 & 56,88 & 326.900 & $-4,85$ \\
\hline 2002 & 67.092 & 11,37 & 327.300 & $-31,95$ \\
\hline 2003 & 76.659 & 14,26 & 325.100 & $-0,12$ \\
\hline 2004 & 73.108 & $-4,63$ & 317.800 & $-2,25$ \\
\hline 2005 & 133.964 & 83,24 & 304.600 & $-4,15$ \\
\hline 2006 & 78.264 & $-41,58$ & 281.900 & $-7,45$ \\
\hline 2007 & 76.090 & $-2,78$ & 261.200 & $-7,34$ \\
\hline 2008 & 78.264 & 2,86 & 245.000 & $-6,20$ \\
\hline 2009 & 73.904 & $-5,57$ & 260.445 & 6,30 \\
\hline 2010 & 83.278 & 12,68 & 251.790 & $-3,32$ \\
\hline 2011 & 60.169 & $-27,75$ & 270.200 & 7,31 \\
\hline 2012 & 47.296 & $-21,39$ & 277.700 & 2,78 \\
\hline 2013 & 70.361 & 48,77 & 281.750 & 1,46 \\
\hline 2014 & 79.784 & 13,39 & 311.560 & 10,58 \\
\hline 2015 & 70.349 & $-11,83$ & & $\mathbf{2 , 6 4}$ \\
\hline
\end{tabular}

\section{Sumber: BPS Provinsi Jambi, 2017 (data diolah)}

Berdasarkan tabel 1. di atas dapat dilihat pada angka pengangguran pada tahun 2000 jumlah pengangguran sebanyak 38.400 orang, tahun 2001 mengalami peningkatan yang cukup tinggi yaitu sebesar 56,88 persen. Peningkatan jumlah pengangguran yang terjadi pada tahun 2002 disebabkan oleh inflasi yang meningkat cukup tinggi yaitu sebesar 20,36 persen, sehingga menyebabkan tingginya biaya produksi sehingga menyebabkan permintaan terhadap tenaga kerja berkurang.

Tahun 2002 jumlah pengangguran meningkat sebesar 11,37 persen, hal ini terjadi karena aktivitas ekonomi Provinsi Jambi menurun menjadi 5,86 persen dan inflasi meningkat 
menjadi 12,62 persen sehingga permintaan terhadap tenaga berkurang. Tahun 2003 meningkat lagi sebesar 14,26 persen, hal ini disebabkan oleh pertumbuhan ekonomi menurun menjadi 5 persen sehingga menyebabkan berkurangnya permintaan terhadap barang dan jasa dan pada akhirnya jumlah pengangguran meningkat.

Tahun 2004 jumlah pengangguran di Provinsi Jambi menurun menjadi 73.108 orang atau menurun sebesar 4,63 persen dari tahun sebelumnya. Penurunan yang terjadi pada tahun 2004 disebabkan oleh meningkatnya kegiatan ekonomi yang ditandai dengan laju pertumbuhan ekonomi meningkat menjadi 5,38 persen. Hal ini menyebabkan aktivitas ekonomi meningkat dan permintaan terhadap tenaga kerja juga meningkat.

Pada tahun 2005 jumlah pengangguran meningkat cukup tinggi yaitu sebesar 83,24 persen, peningkatan yang terjadi pada tahun 2005 merupakan peningkatan yang tertinggi selama periode analisis. Tingginya peningkatan jumlah pengangguran pada tahun 2005 disebabkan oleh inflasi yang cukup tinggi di Jambi yaitu sebesar 16,5 persen, tingkat inflasi pada tahun tersebut merupakan yang tertinggi selama periode analisis. Tingginya tingkat inflasi yang menyebabkan tingginya biaya produksi, sehingga banyak perusahaan yang mengurangi biaya produksi salah satunya dengan mengurangi jumlah tenaga kerja.

Jumlah pengangguran pada tahun 2006 jumlah pengangguran menurun cukup tinggi yaitu sebesar 41,58 persen, penurunan yang terjadi pada tahun 2006 terjadinya peningkatan laju pertumbuhan ekonomi yaitu menjadi 5,89 persen dan penurunan inflasi yang cukup tinggi menjadi 10,66 persen sehingga menyebabkan aktivitas ekonomi meningkat dan menurunnya biaya produksi dan permintaan terhadap tenaga kerja meningkat. Tahun 2007 jumlah pengangguran menurun sebesar 2,78 persen, hal ini disebabkan oleh laju pertumbuhan ekonomi meningkat menjadi 6,82 persen dan inflasi menurun menjadi 7,42 persen sehingga menyebabkan permintaan terhadap barang dan jasa meningkat.

Tahun 2008 jumlah pengangguran meningkat sebesar 2,86 persen, hal ini disebabkan oleh meningkatnya inflasi menjadi 11,57 persen sehingga mengakibatkan tingginya biaya produksi dan permintaan terhadap tenaga kerja menurun. Tahun 2009 jumlah pengangguran kembali mengalami penurunan yaitu sebesar 5,57 persen, hal ini disebabkan oleh meningkatnya aktivitas ekonomi dan tingkat inflasi menurun menjadi 2,49 persen sehingga menyebabkan meningkatnya permintaan terhadap barang dan jasa dan kebutuhan tenaga kerja juga meningkat. 
Pada tahun 2010 jumlah pengangguran meningkat lagi menjadi 83.278 orang atau meningkat sebesar 12,68 persen, hal ini disebabkan oleh terjadinya peningkatan inflasi yang cukup tinggi menjadi 10,52 persen. Sehingga menyebabkan tingginya biaya produksi dalam menghasilkan barang dan jasa, dan akhirnya kebutuhan akan tenaga kerja akan menurun.

Pada tahun 2011 jumlah pengangguran di Provinsi Jambi menurun cukup tinggi yaitu sebesar 27,75 persen dan merupakan penurunan yang tertinggi selama periode analisis, hal ini disebabkan oleh pertumbuhan ekonomi yang cukup tinggi yaitu sebesar 8,58 persen dan merupakan laju pertumbuhan ekonomi Provinsi Jambi yang tertinggi selama periode analisis. Dengan laju pertumbuhan ekonomi yang tinggi mengindikasikan bahwa aktivitas ekonomi yang juga tinggi, hal ini berdampak terhadap peningkatan penyerapan jumlah tenaga kerja.

Pada tahun 2012 kembali lagi mengalami penurunan yang cukup tinggi yaitu sebesar 21,39 persen, hal ini disebabkan oleh investasi meningkat cukup tinggi yaitu sebesar 79,11 persen hal ini menyebabkan meningkatnya permintaan terhadap tenaga kerja. Tahun 2013 meningkat cukup tinggi yaitu menjadi 70.361 orang atau meningkat sebesar 48,77 persen. Peningkatan yang terjadi pada tahun 2013 merupakan peningkatan disebabkan oleh struktur lapangan pekerjaan tidak mengalami perubahan, turunnya produksi sawit dan karet yang merupakan komoditas unggulan di Provinsi Jambi juga menjadi penyebab berkurangnya pekerja di sektor pertanian.

Pada tahun 2014 jumlah pengangguran meningkat lagi yaitu sebesar 13,39 persen, hal ini disebabkan oleh menurunnya laju pertumbuhan ekonomi sehingga menyebabkan permintaan terhadap barang dan jasa berkurang. Pada tahun 2015 turun menjadi 30.349 orang atau turun sebesar 11,83 persen, penurunan yang terjadi pada tahun 2015 disebabkan oleh pertumbuhan ekonomi menurun menjadi 4,21 persen sehingga menyebabkan menurunnya aktivitas ekonomi.

Sementara jumlah penduduk miskin di Provinsi Jambi pada tahun 2000 adalah 504.900 jiwa, tahun 2001 turun menjadi 480.400 jiwa atau turun sebesar 4,85 persen, pada tahun 2002 jumlah penduduk miskin di Provinsi Jambi turun lagi menjadi 326.900 jiwa atau turun sebesar 31,95 persen. Penurunan yang terjadi pada tahun 2002 merupakan penurunan yang tertinggi selama periode analisis, hal ini merupakan dampak dari pembangunan ekonomi kerakyatan yaitu berupa Kredit Usaha Pemberdayaan Ekonomi Masyarakat (KUPEM), dengan KUPEM ekonomi rakyat dapat tumbuh dan berkembang khususnya di sektor pertanian, selain itu adanya 
pengembangan sentra-sentra baru pertanian, hal tersebut dapat meningkatkan kesejahteraan masyarakat Provinsi Jambi.

Tahun 2003 meningkat menjadi 327.300 jiwa atau memingkat sebesar 0,12 persen, tahun 2004 jumlah penduduk miskin di Provinsi Jambi turun menjadi 325.100 jiwa atau turun sebesar 0,67 persen. Pada tahun 2005 turun lagi menjadi 317.800 jiwa atau turun sebesar 2,25 persen. Tahun 2006 jumlah penduduk miskin di Provinsi Jambi turun menjadi 304.600 jiwa atau meningkat sebesar 4,15 persen, pada tahun 2007 jumlah penduduk miskin di Provinsi Jambi turun lagi menjadi 281.900 jiwa atau turun sebesar 7,45 persen. Tahun 2008 jumlah penduduk miskin turun lagi menjadi 261.200 jiwa atau turun sebesar 7,34 persen. Pada tahun 2009 jumlah penduduk miskin di Provinsi Jambi menurun menjadi 245.000 jiwa atau menurun sebesar 6,2 persen.

Pada tahun 2010 jumlah penduduk miskin di Provinsi Jambi meningkat menjadi 260.445 orang atau meningkat sebesar 6,30 persen, tahun 2011 jumlah penduduk miskin di Provinsi Jambi turun menjadi 251.790 orang atau turun sebesar 3,32 persen, tahun 2012 penduduk miskin di Provinsi Jambi mengalami penurunan sebesar 7,31 persen, tahun 2013 jumlah penduduk miskin di Provinsi Jambi meningkat sebesar 2,78 persen dibandingkan dengan tahun sebelumnya.

Pada tahun 2015 jumlah penduduk miskin meningkat cukup tinggi yaitu sebesar 10,58 persen dan merupakan peningkatan yang tertinggi selama periode analisis. Hal ini disebabkan oleh melemahnya perekonomian Provinsi Jambi dengan laju pertumbuhan ekonomi sebesar 4,21 persen, melemahnya perekonomian menyebabkan meningkatkan aktivitas ekonomi melemah dan kesejahteraan juga akan menurun.

Ada beberapa faktor yang perlu menjadi catatan dalam kaitannya antara pertumbuhan ekonomi dengan kemiskinan dan pengangguran, Pertama, pertumbuhan ekonomi yang tinggi dengan ditopang oleh sektor-sektor yang memiliki elastisitas lapangan kerja rendah, tidak akan menyelesaikan masalah kemiskinan. Pertumbuhan ekonomi seperti ini umumnya lebih memberikan keberpihakan kepada pengembangan sektor sektor tertentu sehingga mempersempit peluang berkembangnya sektor lain, yang pada akhirnya akan berakibat pada berkurangnya jenis lapangan kerja yang tersedia. Kedua, pertumbuhan ekonomi yang tinggi namun ditopang oleh keberadaan industri milik negara yang memperoleh sejumlah proteksi tertentu juga tidak menjamin akan dapat menyelesaikan kemiskinan. Ketiga, pertumbuhan ekonomi yang tinggi dengan ditopang oleh industri canggih juga berpotensi untuk 
memperparah masalah kemiskinan dan pengangguran jika struktur tenaga kerja yang ada didominasi oleh tenaga kerja berkemampuan rendah (low skill labour). Keempat, pertumbuhan ekonomi yang tinggi akan tetapi dengan ditunjang oleh kekuatan ekonomi yang bersifat terkonsentrasi juga tidak akan sanggup mengatasi masalah kemiskinan. Di samping itu, setidaknya beberapa penyebab masih tingginya kemiskinan dan pengangguran adalah : Iklim investasi yang belum kondusif (kepastian hukum dan kelambanan birokrasi), investasi pemerintah yang belum optimal dalam penyediaan fasilitas publik, faktor eksternal ekonomi global (melambatnya laju pertumbuhan ekonomi global dan melambungnya harga minyak).

\section{b. Hubungan Pengangguran dan kemiskinan di Provinsi Jambi}

Hasil analisis menunjukkan bahwa terdapat hubungan negatife antara jumlah pengangguran dan kemiskinan dengan nilai korelasi sebesar -0,340 (negative). Artinya jika terjadi peningkatan jumlah pengangguran yang terjadi di Provinsi Jambi akan menyebabkan meningkatnya jumlah kemiskinan di Provinsi Jambi dan sebaliknya ketika terjadi penurunan jumlah pengangguran akan menurunkan jumlah kemiskinan.

\section{KESIMPULAN DAN SARAN}

\section{a.Kesimpulan}

Dari hasil penelitian menunjukkan bahwa secara rata-rata peningkatan pengangguran selama tahun 2000-2015 adalah sebesar 8,53 persen sementara jumlah kemiskinan secara rata rata mengalami penurunan sebesar 2,64 persen dan terdapat korelasi yang negative antara peningkatan jumlah pengangguran dan peningkatan jumlah kemiskinan.

\section{b.Saran}

Beberapa saran yang dapat dilakukan adalah perlunya identifikasi secara akurat daerahdaerah yang menjadi sasaran penanggulangan kemiskinan multidimensi agar pemerintah dapat menyusun program kegiatan yang sesuai dengan kebutuhan yang ada dan tepat sasaran dan pemerintah harus berupaya untuk menciptakan lapangan pekerjaan sehingga mampu menampung dan mengurangi pertumbuhan tenaga kerja yang ada.

\section{DAFTAR PUSTAKA}

Aurangzeb. (2013). Factors Effecting Unemployment: A Cross Country Analysis. International Journal of Academic Research in Business and Social Sciences, 3(1).

Dornbusch, R., Fischer, S., \& Startz, R. (20080. Makroekonomi. Edisi Kesepuluh. Media Global Edukasi, Jakarta. 
Egunjobi., \& Titilayo, . (2014). Poverty and Unemployment Paradox in Nigeria. IOSR Journal of Humanities and Social Science (IOSR-JHSS), 19(5) 106-116.

Gujarati, D. (2003). Ekonometrika Dasar. (Edisi Alih Bahasa Terjemahan). Jakarta: Erlangga.

Harlik. (2013). Faktor-faktor yang Mempengaruhi Pengangguran dan Kemiskinan di Kota Jambi. Tesis, Universitas Jambi.

Irmanelly, I., \& Soleh, A. (2013). Analisis Sektor Unggulan dan Hubungannya dengan Ketenagakerjaan dan Kemiskinan di Provinsi Jambi. Jurnal Development, 1(1), 15-43.

Riduan, 2016. Determinan Kemiskinan di Provinsi Jambi. Tesis. Program Magister Ilmu Ekonomi-UNJA. Jambi.

Soleh, A. (2017). Masalah Ketenagakerjaan dan Pengangguran di Indonesia. Cano Ekonomos, $6(2), 83-92$.

Soleh, A. (2016). Analisis Pertumbuhan Ekonomi Indonesia. Jurnal Development, 4(2), 18-26.

Soleh, A. (2018). Analisis dan Strategi Pengentasan Kemiskinan Di Provinsi Jambi. EKSIS: Jurnal Ilmiah Ekonomi dan Bisnis, 9 (1), 79-90.

Soleh, A. (2019). Pengaruh Pertumbuhan Ekonomi Dan Belanja Modal Terhadap Indeks Keparahan Kemiskinan Di Provinsi Jambi. Pareto: Jurnal Ekonomi dan Kebijakan Publik, 2(1), 15-24.

Soleh, A. Analysis Of Comparative Of Regional Poverty: A Case Of Indonesia.

World Bank. 2004. Mewujudkan Pelayanan Umum bagi Masyarakat Miskin. The World Bank, Jakarta.

World Bank, 2007. World Development Report : Pembangunan dan Generasi Mendatang. Salemba Empat. Jakarta. 